\title{
Physical Examination Collection Date Time
}

National Cancer Institute

\section{Source}

National Cancer Institute. Physical Examination Collection Date Time. NCI Thesaurus.

Code C83342.

The date and time of a physical examination. 